\author{
A C T A U N I VERS ITA T IS L O D Z IEN S IS \\ FOLIA OECONOMICA 6(326) 2016 \\ http://dx.doi.org/10.18778/0208-6018.326.01
}

\author{
Beata Anna Glinkowska*
}

\title{
PATHS OF INTERNATIONALIZATION OF POLISH ENTERPRISES
}

\begin{abstract}
The variability of the environment, saturation of the domestic market, the need to remain competitive, etc. require enterprises to search for new solutions in the fields of management and operation. Managers are confronted with new challenges. The internationalization of enterprises became an increasingly occurring pattern of cooperation and collaboration, resulting from the need to seek new markets and new opportunities, as well as the need to survive on the market. The article presents some chosen aspects of internationalization of enterprises, with a particular focus on the specifics of the internationalization of Polish companies of micro, small and medium size. The article presents the motives that guide entrepreneurs and managers, allowing them to expand their business activities to foreign markets. Also, it shows the barriers, which occur most frequently in the process of internationalization. The conducted empirical studies became the basis for presenting the ways of internationalization of Polish enterprises from the SME sector. The results were then referred to the conditions present in Poland and to the existing models. The article was written based on the analysis of literature and own research.
\end{abstract}

Keywords: internationalization, SMEs, innovation, international company

JEL: F23

\section{INTRODUCTION}

The internationalization of enterprises is a general term, occuring mainly within the context of the globalization of markets (Lichtarski 2001: 93). The ongoing process of companies' internationalization is a hallmark of modern economy (Rymarczyk 1996: 17). Increasing competition on the stem markets, promotes entrepreneurial activities towards expansion of companies into foreign markets (Daszkiewicz, Wasilczuk, Dominiak 2005: 5-7). The most common form of this process is international trade, the most commonly understood as export and import. In the literature, the internationalization of businesses consists of placing subsidiaries, branches and representative offices in many countries (Rugman 1980: 23-29), including networking between different organizations in the world. In general it is a process of transformation of Polish

\footnotetext{
*Katedra Zarządzania, Wydział Zarządzania, Uniwersytet Łódzki, e-mail bettysue@uni.lodz.pl
} 
companies into international ones. Its intensity, form and range depend on the strategy of development and growth of these companies. This study examines the various ways of internationalization of Polish companies in the small and medium-sized enterprises sector. When examining the ways of internationalization, questions were also asked about the barriers to and motives for initiating this process within enterprises. From 2012 to 201421 companies in total were examined from the province of Lodz, within the micro, small and medium-sized enterprises sector. The companies involved were from various branches of the industry and of varying degrees of cooperation with foreign countries. All companies have been operating on the market for over two years. Seven of them have been established in the nineties of the twentieth century. All companies demonstrate "foreign activity", which was a criterion for the selection of the surveyed companies. We hypothesized that in Polish reality, there is no single dominant mode of internationalization of enterprises, also that there are many barriers for small and medium-sized businesses to undergo this process. The adoption in the studies of the need to identify the barriers seems right, because according to the author they determine the amount and type of ways of internationalization of enterprises. The ways of internationalization of Polish companies were compared to the Swedish model and the model described by J. Cieślik (1987: 12-14). However, the emphasis was placed on the diversity of ways of internationalization of Polish enterprises from the SME sector. The questionnaire interviewed the owners or managers of surveyed companies. The total number of respondents was 39. The results are presented in such a way that if more than one person was tested in the company, and the answers were consistent, they were treated as one company, hence in the part of the report on the research results, there are 21 cases. The author is aware of the nonrepresentativeness of the test results, however, this number does give some insight into the internalization processes, and these studies will be continued and developed on other - larger units.

\section{INTERNATIONALIZATION OF COMPANIES - CHOSEN ASPECTS}

The factors which greatly accelerate and make easier the process of internationalization of enterprises include: increasing the scope of the so-called supranational regulations, such as common standards, environmental standards, technical, quality, ethical, etc., providing equal access to an integrated market and free flow of capital, or creating common markets. The internationalization of the organization is also accelerated by free movement of the capital and the liberalization of markets. Under such conditions, there is a process of integration 
of capital and company. J. Witkowska and Z. Wysokińska emphasize the benefits of the integration from internal and external points of view: the development and growth of a company strengthen its competitive position, make access to the capital and to innovative solutions easier, allow for the achievement of greater economic effects and speed up the exchange of knowhow between companies (Witkowska, Wyskokińska 2006: 45-46). Removing administrative, political and market barriers between the countries and the introduction of various facilities and improvements in trade and communication are an important element influencing the speed, efficiency and effectiveness of the process of internationalization of enterprises.

The issues of internationalization of companies in the micro, small and medium-sized enterprises (SMEs) is a relatively recent one (late 90s of the twentieth century). Internationalization of companies is supported by a number of motives, but is characterized by the existence of many barriers. A number of definitions related to the process of internationalization of enterprises exists mainly due to the range of perspectives of the researchers. J. Johanson and J.R. Vahlne perceive internationalization as any activity undertaken abroad (Johanson, Vahlne 1977: 19-23). J. Schumpeter gives it the characteristics of organizational innovation (Schumpeter 1960: 93). For E.A. Dörnberg internationalization is a statistics phenomenon (Dörnberg 1982: 93). N. Daszkiewicz notices that internationalization should not be associated with globalization or exports (Daszkiewicz 2004: 14-15). For J. Rymarczyk internationalization is " $(. .$.$) any type of business undertaken by an enterprise$ abroad" (Rymarczyk, 2004: 19) and for G. Gierszewska and B. Wawrzyniak it is the whole flow of factors of production between countries (Gierszewska, Wawrzyniak 2001: 17-21). While others (R. Mead and T.G. Andrews) did not take on defining the internationalization process but determined the notion of a global industry (Mead, Andrews 2011: 310). The companies that possess advanced technologies and managers with the highest competence undergo the internationalization much faster (Nogalski, Daszkiewicz 2005). The degree of internationalization of the company is difficult to measure because it requires use of multiple quantitative and qualitative indicators, such as:

- The number of foreign markets it serves;

- Contribution of profits coming from abroad to the total profit of the company;

- Contribution of the value of assets abroad to the total company assets;

- Contribution of the company and its products to the foreign markets;

- The scale of direct foreign investment;

- Contribution of workers employed abroad to the company's total employment (Rymarczyk 2004: 24). 
In Poland, we often use the criteria of the process of internationalization cited in the OECD report, according to which international companies are those which raise at least $10 \%$ but less than $40 \%$ of production factors from abroad, and at least $10 \%$ but less than $40 \%$ of revenue from abroad (OECD 2007). The author, confronting different approaches and definitions, assumes that the internationalization of business means any type of business activity that requires contact with the foreign market or takes place in a foreign market.

\section{MOTIVES AND BARRIERS IN INTERNATIONALIZATION OF POLISH ENTERPRISES}

There are many motives for internationalization of small and medium-sized enterprises. The most common motives are the costs of activities related to prices of raw materials, labor costs and transportation costs (Witkowska, Wysokińska 2006: 17). Often, higher costs in Poland, become a reason to search for new markets abroad. The study made by the author in 2012-2014 (as part of the statutory activities) have proven the validity of the division proposed by J. Rymarczyk (2004: 58 and next) that all the motives guiding the owners and managers of SMEs with internationalization decisions can be classified into motives of nature, cost, market, supply and political life. The research also identified reasons that go beyond these four areas, resulting mainly from individual and unusual motives, for example: snobbery, fashion, trends. Some researchers also mention such themes as:

- Input of key customers into foreign markets;

- The existence of concentration processes in the industry;

- The need to cut the costs (Matthyssens, Pauwels, Vandenbempt 2001).

However, the possibility of opening to new markets, the ability to reduce production costs, including labor costs, making favorable investments, cutting the purchase price of raw materials, as well as more liberal tax laws in other countries, are key themes in the process of internationalization of Polish companies from the micro, small and medium sector. Internationalization takes place in various ways and therefore there are different motives for companies to "leave" their home country. For example, companies cooperating with other countries on the basis of export, give the following reasons for their cooperation (Table 1) ${ }^{1}$ :

\footnotetext{
${ }^{1}$ The order of themes according to their importance (weight) for respondents; first 9 selected.
} 
Table 1. Motives of internationalization for exporting companies

\begin{tabular}{|l|}
\hline- Increase of the company's revenue \\
\hline- Gaining a greater gross margin per each item sold \\
\hline- The desire for quick earnings \\
\hline- The willingness of development through product diversification \\
\hline- The willingness of development through technology diversification \\
\hline- Willingness to development through diversification technologies \\
\hline- Declining sales opportunities in domestic market \\
\hline- Increasing number of domestic competition \\
\hline- The desire to find a niche in the foreign market or so-called market-expansion \\
\hline- Existence of loopholes, occasion-related laws in the country which the company intends to enter \\
\hline
\end{tabular}

Source: own elaboration.

In contrast, companies cooperating with foreign companies on the basis of import are guided by the following themes (Table 2$)^{2}$ :

Table 2. Motives of internationalization for importing companies

\begin{tabular}{|l|}
\hline $\begin{array}{l}\text { - Lower purchasing costs: raw materials, semi-finished or finished products (costs lower than in } \\
\text { Poland) }\end{array}$ \\
\hline - Use of so-called loopholes in the law to avoid the additional costs (e.g. related taxes) \\
\hline - Lack of suitable raw materials in Poland \\
\hline - Unique product or innovation, making it a niche product for sales in Poland \\
\hline - Desire to earn a higher margin on trading activities (cheaply bought, sold more expensive) \\
\hline- Knowledge of a particular foreign market \\
\hline- Knowledge of relevant people from abroad, which greatly facilitates contacts \\
\hline- Diversification of suppliers \\
\hline- Prestige
\end{tabular}

Source: own elaboration.

Respondents whose companies are involved in both export and import, are guided by both of the presented sets of motives.

There are many barriers to starting cooperation with foreign market organizations. H. Adebahr cited among them: the stagnation in the domestic market, absence of full production capacity on the existing market, increase in number and strength of the competition, law changes, which introduce more restrictions in the home country (Adebahr 1980: 13). S.T. Cavusgil is of the opinion that there are four kinds of obstacles in the process of internationalization of enterprises: internal - domestic; internal - foreign; external - national; external - foreign (Cavusgil 1984: 12).

\footnotetext{
${ }^{2}$ Themes by relevance assessed by the respondents; first 9 selected.
} 
Studies made by the author confirm the existence in practice of most of the barriers described in the literature, and faced by small Polish companies. However, different sets of barriers apply to companies engaged in exports, while other to companies cooperating with foreign countries on the basis of import.

Entrepreneurs from exporting companies mention the following barriers to internationalization $(\text { Table } 3)^{3}$ :

Table 3. Barriers to internationalization for exporting companies

\begin{tabular}{|l|}
\hline $\begin{array}{l}\text { - Lack of information on foreign markets and related to it: operating conditions in the market of } \\
\text { the country }\end{array}$ \\
\hline- Lack of contacts (colleagues, friends, associates abroad) \\
\hline - Lack of knowledge of regulations in the country \\
\hline- Fear of making mistakes associated with the documentation or the law \\
\hline- Lack of direct access to markets \\
\hline- Tariffs on foreign markets \\
\hline- Fear of insufficient quality of the offered products \\
\hline- High costs of claims and warranties \\
\hline- Problems with communication and flow of information related to the distance of the foreign \\
market and language barriers
\end{tabular}

Source: own elaboration.

Entrepreneurs from importing companies mention the following barriers (Table 4) ${ }^{4}$ :

Table 4. Barriers to internationalization for importing companies

\begin{tabular}{|l|}
\hline- Fear of lack of robustness on the part of a potential cooperator \\
\hline - Lack of knowledge of foreign markets \\
\hline - Ignorance of the laws in the foreign country \\
\hline - Fear of making mistakes associated with the documentation or the law \\
\hline - Temporary barrier associated with transport \\
\hline $\begin{array}{l}\text { - Lack of direct contact and the consequent fear of insufficient quality of the raw material and } \\
\text { material goods }\end{array}$ \\
\hline- Costs of transport and delivery \\
\hline- Language barriers \\
\hline - Lack of capital \\
\hline
\end{tabular}

Source: own elaboration.

\footnotetext{
${ }^{3}$ Barriers according to their severity assessed by the respondents. First 9 selected.

${ }^{4}$ Barriers according to their severity assessed by the respondents. First 9 selected.
} 
It may be noted that the lack of information about conditions, laws and fear of committing mistakes on the foreign market, are the main barriers on the way to internationalization of the surveyed enterprises.

Increasingly important is also the issue of innovation of companies. It seems that innovative companies are more attractive for foreign companies and countries.

Polish Confederation of Private Employers, Lewiatan, for example, performed a study on a group of private SMEs enterprises in Poland. Their goal was to answer the questions concerning, inter alia, the impact of innovation on the level of competitiveness of small and medium-sized enterprises (Raport PKPP Lewiatan 2006). The results show, that among the factors determining the competitiveness of companies are:

- Narrow specialization;

- Specialized knowledge and skills;

- The ability to adapt production to customer requirements.

Interestingly, the least important in the study was the innovative nature of the products and services. When researchers asked whether innovative activities are useful for companies, most traders responded positively. However, as noted previously, what limits managers' and owners' innovative behaviours, are the costs and risks that can be reduced by e.g. support from public funds allocated to innovation (tax relief, access to credit on preferential terms) ${ }^{5}$.

The most important factors that increase business innovation include: reductions in taxes associated with the introduction of new technologies $(53.5 \%$ of responses), access to credit on preferential terms (46\% of responses), demand on the domestic market for innovative products (43.6\% responses). An important factor limiting the tendency to innovate is the lack of knowledge about innovative solutions, which are available to small and medium-sized enterprises. To increase the propensity for innovation in organizations, it is necessary to:

- Remove barriers to access to capital (24.6\% of responses); be able to export goods (18.3\%);

- Possess knowledge of innovative solutions in promotion and distribution $(13.5 \%)$;

- Obtain tax allowances associated with starting your own research $(11.7 \%)$;

- Have knowledge of innovative solutions for manufactured products $(11.2 \%)$;

- Have knowledge of the research conducted in Poland, the results of which can be applied within the company (9.6\%);

${ }^{5}$ Different types of support for entrepreneurship have been introduced by the Act on supporting innovative activities, which entered into force at the beginning of 2006. 
- Know innovative solutions for the management of the company (9.1\%);

- Compete with other strong companies within the industry (5.0\%) (Raport PKPP Lewiatan 2006).

The study also presents, that in the industrial corporations sector, the amount of innovation active enterprises is $16.9 \%$ (against $18.1 \%$ in $2008-2010$ ), while in the service sector this amount fell from $13.5 \%$ to $12.3 \%$. There was also a fall in the net revenue from sales of new or changed (improved) products by $2.4 \%$ compared to the years 2008-2010. About $11 \%$ of companies that have achieved considerable success in innovative industries are large companies (over 250 employees). This may mean that the sector of small and medium-sized enterprises encounters problems with financing innovation (Raport GUS 2012: 37-45). The overall level of innovation and the level of the individual types of innovation (product, process, technology, marketing) decreased significantly in 2009-2011 comparing to 2006-2008 in Poland, not only in the Lodz region (Raport GUS 2012: 37-45). In 2011, the estimated expenditure on innovative activities amounted to 20.8 billion PLN, which means a drop of $12.4 \%$ in comparison to 2010 (Raport GUS 2012: 55). It is interesting that in the service sector, expenditure on innovation, estimated at 11 billion PLN, has increased by $1.7 \%$ in comparison to 2010. Most of the expenditures on innovation come from the private sector. Expenditures in the group of large enterprises amounted to $72.5 \%$ of total expenditures devoted to innovation activities (Raport GUS 2012: 55). Considering geographical criterion, the biggest investment in innovation in 2011, in the industrial enterprises sector, was recorded in Silesia. Lodz region takes the third position within this category. (Raport GUS 2012: 57).

\section{METHODS FOR THE INTERNATIONALIZATION OF MICRO, SMALL AND MEDIUM-SIZED ENTERPRISES - RESULTS}

The surveyed companies, in most cases, are companies involved in trade and services. There are a few companies of a manufacturing or production and service nature. The questionnaire was addressed to the owners or managers of surveyed companies (39 people in 21 companies). This deliberate selection was used in connection with certain criteria. These criteria include: the existence of foreign activity of the company (on the Polish market with companies from abroad, or in the foreign market as a direct foreign investment); the existence of the company for at least two years; headquarters of the company located in Lodz region. The companies accepted for testing belong to the sector of micro, small and medium-sized companies and cooperate in various ways with foreign countries. Moreover, they belong to different industries and sectors and their registered offices (or branches) are in the Lodz region. Their owners and/or 
managers agreed to participate in the study. The cross-section of companies is as follows: companies from the retail sector (6 clothing stores, 3 grocery shops, 3 food warehouses); companies from the construction industry (3 companies); companies from production and trade industry (4 companies producing clothing and selling it abroad: France, Germany); companies from the furniture industry ( 2 companies). In total: 7 micro, 11 small and 3 medium-sized companies (Figure 1).

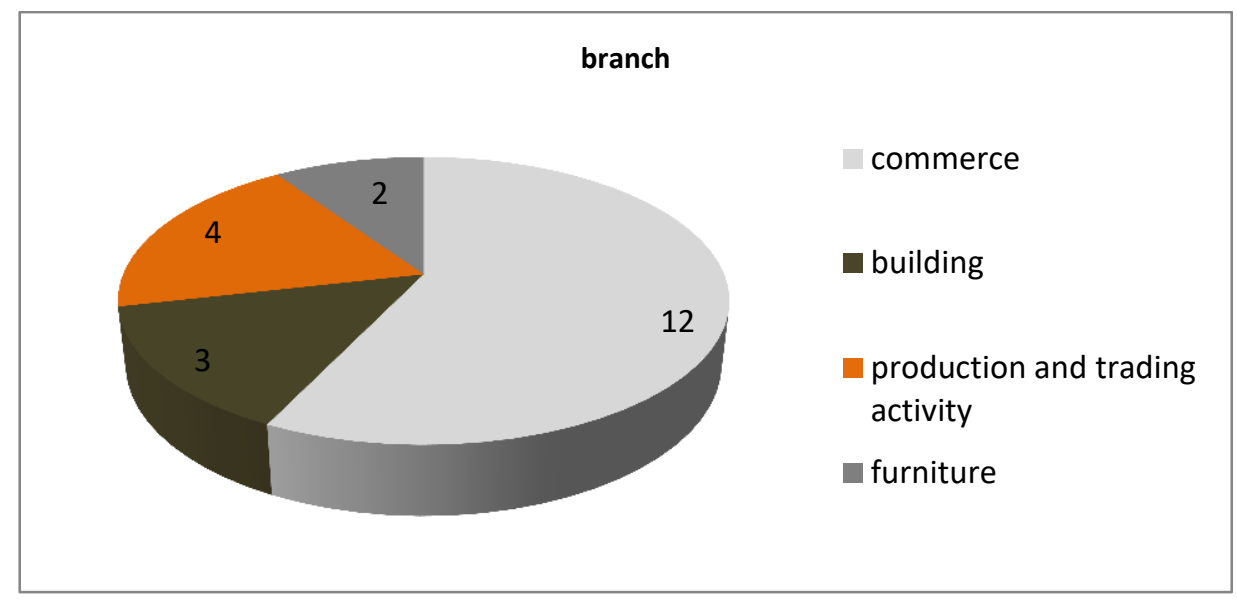

Figure 1. Structure of surveyed companies by sector

Source: own elaboration.

Due to the volume limitations of this study the obtained research results were thoroughly analyzed and presented in a narrative form below. Polish resources of micro, small and medium-sized companies are relatively small, so the most common form of internationalization of companies surveyed is export or import, or both simultaneously. It is the case for 16 out of the 21 companies (76.19\%), while 5 companies (23.81\%) collaborate with other countries on the basis of lasting relationships, which is a higher form of internationalization process. None of the companies launched foreign direct investment (FDI), but one is currently considering this option. In addition, in one of the reported cases, the management contract was signed due to the high competences of the managerial staff (CNC technology). The same company is also striving to achieve strategic alliance with a partner from Germany. One of the companies has been cooperating with the Chinese market (wholesale toys) for 6 years and two companies sustain permanent cooperation with Germany and France in terms of clothing orders. Based on the limitations resulting from a small sample, 
we cannot, in this case, talk about the frequency of occurrence of a particular form of internationalization, but the analysis of own research results and data from the Central Statistical Office indicate that the most common form of internationalization of enterprises in Poland is export and import.

In the studied cases, one may observe different ways of internationalization. The entry way of a company to foreign markets depends on many circumstances. The most important premises are, among others: the resources of a company; type of foreign market; politics of the home country and the host country; the existence of potential barriers of variable nature. Widely W.J. Otta, proposes, in connection with various business situations, different strategies for entering foreign markets (Gołębiowski 1994: 54). The choice of a path of internationalization should take into consideration the risk associated with an entry onto a particular foreign market. Such risk will vary depending on whether a company only exports its products abroad or actually has branches or subsidiaries abroad. Various strategies may involve the sale of licenses, direct investment, or even export via the company's own branch abroad. The internationalization paths are determined by the use of resources and the type of business. Export, or import does not require companies to have their own human resources outside the country. They should be adequately prepared to enter the foreign market and function on it. Mentioned herein forms and ways of internationalization of companies require preparation of a specific plan of action, course of action, taking into account opportunities, but also threats. Internationalization strategy is strongly correlated with the strengths and weaknesses of companies, therefore we can assume that companies will use a variety of strategies appropriate to their capabilities and environmental conditions. Internationalization strategies were not the main issue addressed in this study. The author is in the process of constructing an extensive survey, which she intends to pass on to other companies, and publishing of the research results, which will be included in a book on specific case studies. The book will also include the strategies for the internationalization of Polish companies.

For now, the research has shown that Polish companies have not developed a one particular model of internationalization, which could be applied by all enterprises. It has also recognized the specifics of the internationalization of Polish companies. Export and import appear to be the most conventional ways of internationalization. It is the result of many factors, among which the most important are: simplicity, lack of need to involve large capital, lower purchasing costs in case of import, the possibility of selling goods when the domestic market is saturated but above all, a relatively (to other forms) low risk. The study confirmed the validity of assumption that in Polish reality, there is no single dominant mode of internationalization of enterprises, and the companies' ways of "going beyond the borders" are largely dependent on the motives and 
the barriers that are described in section 2 of this paper. However, export and import are favorable forms of gaining experience for further expansion of the company. Most respondents function on the basis of export and import capabilities (85.71\%, 18 companies surveyed). The lack of good knowledge of the language, transportation costs and extensive bureaucracy are serious barriers for small Polish companies. Respondents, however, are convinced that they would like to start a regular and permanent cooperation with foreign partners. For this, they need stability, reliable partners and a well-developed relationship.

An explanation of the stages of the process of internationalization of enterprises can be found in literature. E. Dulfer grouped companies by virtue of their presence abroad, to:

- Those which do not require to be present abroad in an organized and continuous way (export, import, barter, franchising, leasing);

- Those which require constant and continuous presence abroad (branch/subsidiary of Commercial/assembly/manufacturing management contract/ the construction of "turnkey", etc.) (Dulfer 1992).

For this reason, the enterprises surveyed by the author of this article are included into the group which does not require the constant presence abroad. The author agrees with E. Dufler, that in this case, there is no need to specify the stages of internationalization of enterprises. This is in contrast to the opinion of M. Czinkota and W. Johnston, who emphasize stages in this process (Czinkota 1981: 23). Luostarinen R. and H. Hellman, while analyzing the behavior of small businesses in Finland, also pointed out the steps existing in the process of internationalization of a company: activity on the domestic market; internal internationalization; external internationalization; cooperation (Virtanen 1993). A. Buckley does not endorse this view, noting that companies enter foreign markets using various ways of internationalization, and these in turn are dependent on the nature of those markets (Buckley, 2002: 93). Y. Aharoni also notes that the willingness of the company for internationalization, as well as the progress of this process, is highly influenced by previous experience and commitment of the owners and managers of said company. (Aharoni 1966: 71). Analyzing literature further, one can observe quite a flexible and versatile model, which matches the point of view of the author, as it is close to the specifics of Polish companies, starting the international cooperation. This model was developed in the 1980' at Uppsala University in Sweden, and its authors are J. Johanson and I Vahlne (1977: 23). In this context, export and import tend to be initial steps on the road to internationalization of Polish companies in the sector of micro, small and medium enterprises. This model is in agreement with the author's own observations raised in other studies. While organising the above conclusions, one can observe that in the literature on the subject, some models are similar in their nature. As for the Polish specifics, after careful 
analysis of the available literature models, the greatest similarity in the process of internationalization of Polish companies can be drawn to a stepwise Swedish model (Uppsala, sequential model).

In its logic, the Swedish model could also be compared to the model of an internationalization process proposed by J. Cieślik, who believes that the internationalization of companies is continuous and cumulative, which is reflected in the growing number of foreign operations within the total of the enterprise's activity and in the transition from simple to increasingly complex forms of cooperation. Still, we should not forget about Polish small and "young" companies which, with their young and enterprising owners, fluent in foreign languages and benefiting directly from the globalization and liberalization of markets, immediately enter the territories of other countries with their product or service, which resembles assumptions of the model "born global".

\section{SUMMARY}

Conducting own research, the author observed many features of Uppssala and J. Cieślik models of internationalization among the surveyed companies:

- process of internationalization progresses sequentially from occasional import/export activities, through the establishment of strict and fairly regular cooperation, to the desire for opening of sales offices or production lines in the territory of the country with which the cooperation was undertaken;

- as the company grows, the number of foreign operations increases and simple forms of co-operation become increasingly more complex.

In the course of empirical studies the following conclusions have been reached:

- lack of data, information, and consequently knowledge of the international market is a fundamental barrier to entry into this market;

- experience gain (and as a result the acquisition of knowledge about the foreign market) is the first barrier associated with ignorance and fear of the start to be overcome. This allows the company to achieve a "higher level" of internationalization;

- the commencement of lasting cooperation with a foreign market and the increase of involvement in it, are the next steps in the process of a company's presence at the said market.

- entrepreneurship and enthusiasm of young managers and business owners is an important determinant for starting internationalization.

The above cited model is not universal, however, it seems to fit the Polish SME sector and its individualized ways of internationalization. The so-called "Polish model" has its own characteristics associated with the economic 
transformation, involving the transformation of a centrally planned economy to a market economy. However, the Polish model of internationalization seems to be more based on Swedish assumptions than American. There are also Polish companies experienced in the area of foreign direct investment. It is a model often characterized by the presence of chances and opportunities in the process of entering the foreign markets where export and import are the dominant forms of business. Lack of typical - seen in other models - features of the process of internationalization is mainly due to historical, economic, political and social circumstances of Polish economy. The evolution of "Polish model" continues, and the author is convinced that liberalization of markets and the deepening of globalization together with its boon of free flow of information and individuals will be the basic reason for acceleration of this process. The driving force behind the modern ways of entering businesses to foreign markets seems to be: innovation, creativity and the ability to communicate. Those conditions require a new approach to managing of today's international companies (Skiba, Czarnecka 2014: 178-187).

\section{REFERENCES}

Adebahr H. (1980), Auslandsaktivitäten deutsche Unternehmen - Chancen der Zukunftssicherung, Deutsche Gesellschaft für Betriebswirtschaft, Köln, Dortmund.

Aharoni Y. (1966), The Foreigen Investment Decision Process, Harvard Graduale School of Business, Cambridge, MA.

Buckley A. (2002), Inwestycje zagraniczne. Składniki wartości i ocena, PWN, Warszawa.

Cavusgil S.T. (1984), Differences among exporting firms based on their degree of internationalization, "Journal of Business Research" vol. 12, issue 2, p. 195-208.

Cieślik J. (1987), Zarys teorii internacjonalizacji przedsiębiorstwa, SGPiS, Warszawa.

Czinkota M., Johston W. (1981), Segmenting U.S. Firms for Export Development, "Journal of Business Review", no. 4, p. 19-23.

Daszkiewicz N., Wasilczuk J., Dominiak P. (2005), Małe i średnie przedsiębiorstwa wobec procesów integracji gospodarki światowej - teoria i metodologia badań, [in:] P. Dominiak, J. Wasilczuk, N. Daszkiewicz (eds.), Mate i średnie przedsiębiorstwa w obliczu internacjonalizacji i integracji gospodarek europejskich. Przykłady Francji, Włoch, Czech i Polski, Wydawnictwo SPG, Gdańsk.

Daszkiewicz N. (2004), Internacjonalizacja matych i średnich przedsiębiorstw we współczesnej gospodarce, Wydawnictwo SPG, Gdańsk.

Dulfer E. (1992), Internationales Magagement In unterschiedlichen Kulturbereichen, O.Oldenbourg Verlag, Munnchen-Wien.

Dörnberg E.A. (1982), Die Internationalisierung mittelständischer Industrieunter-nehmungen Auswirkungen auf Organisationsstruktur und Führungsstil, Gottingen, Vandenhoeck, Ruprecht.

GUS (2012), Działalność innowacyjna przedsiębiorstw w latach 2009-2011, Warszawa.

Gierszewska G., Wawrzyniak B. (2001), Globalizacja. Wyzwania dla zarządzania strategicznego, Poltext, Warszawa.

Glinkowska B. (2014), Internacjonalizacja przedsiębiorstw - zagadnienia wybrane, [w:] Ł. Skiba, A. Czarnecka (eds.), Nowe kierunki w zarządzaniu wspótczesnymi organizacjami, Sekcja Wydawnictw Wydziału Zarządzania Politechniki Częstochowskiej, Częstochowa. 
Gołębiowski T. (ed.) (1994), Przedsiębiorstwo na rynku międzynarodowym. Analiza strategiczna, PWN, Warszawa.

Johanson J., Vahlne J.E. (1977), The Internationalization Process of the firm - A Model of Knowledge Development and Increasing Commitments, "Journal of International Business Studies" 8, vol. 8, p. 22-23.

Lichtarski J. (ed.) (2001), Podstawy nauki o przedsiębiorstwie, Wydawnictwo Akademii Ekonomicznej im. Oskara Langego we Wrocławiu, Wrocław.

Luostarinen R., Hellman H. (1993), Internationalization Process and Strategies of Finnish Family Enterprise, [in:] M. Virtanen (ed.) Proceedings of the Conference on the Development, "Ministry of Trade and Industry, Studies and Raports", no. 59, p. 2-37.

Matthyssens P., Pauwels P., Vandenbempt K. (2001), Strategic Behavior in Globalizing Markets: Case Studies on the Internationalization of Mid-Sized MNEs, [in:] Preceedings of $6^{\text {th }}$ Workshop in International Business, University of Vaasa.

Mead R., Andrews T.G. (2011), Zarządzanie międzynarodowe, Wolters Kluwer Polska, Warszawa.

Monitoring kondycji sektora matych i średnich przedsiębiorstw 2006 (2006), PKPP Lewiatan, Warszawa.

Nogalski B., Daszkiewicz N. (2005), Internacjonalizacja polskich małych i średnich przedsiębiorstw przymus czy swobodny wybór, [in:] Strategie korporacji działajacych $w$ skali ponadnarodowej, Komitet Nauk Organizacji i Zarządzania PAN, Tychy.

OECD (1997), Globalisation and small and medium enterprises, Paris.

Rugman A.M. (1980), A New theory of the multinational enterprise, internationalization versus internationalization, "Columbia Journal of World Business", t. 15, vol. 33, p. 76-78.

Rymarczyk J. (1996), Internacjonalizacja przedsiębiorstwa, PWE, Warszawa.

Rymarczyk J. (2004), Internacjonalizacja i globalizacja przedsiębiorstwa, PWE S.A., Warszawa.

Schumpeter J. (1960), Teoria rozwoju gospodarczego, PWN, Warszawa.

Witkowska J., Wysokińska Z. (2006), Umiędzynarodowienie matych i średnich przedsiębiorstw a procesy integracji europejskiej. Aspekty teoretyczne i empiryczne, Wydawnictwo Uniwersytetu Łódzkiego, Łódź.

http://portalwiedzy.onet.pl/88268,,,,internacjonalizacja,haslo.html [Dostęp 07 VII 2015]

\section{Beata Anna Glinkowska}

\section{DROGI INTERNACJONALIZACJI POLSKICH PRZEDSIĘBIORSTW}

Streszczenie: Zmienność otoczenia, nasycenie rynku krajowego, konieczność pozostania konkurencyjnym itp. wymusza na przedsiębiorstwach poszukiwanie nowych rozwiązań w sferze gospodarowania i funkcjonowania. Stawia przed menedżerami nowe wyzwania. Internacjonalizacja przedsiębiorstw to coraz częściej występujący sposób kooperacji i współpracy, wynikający z konieczności poszukiwania nowych rynków zbytu, nowych możliwości, czy przetrwania. W artykule przedstawiono wybrane aspekty internacjonalizacji przedsiębiorstw, ze szczególnym uwzględnieniem specyfiki internacjonalizacji polskich firm o mikro, małej i średniej wielkości. Przedstawiono motywy, którymi kierują się przedsiębiorcy i menedżerowie, pozwalające z działalnością gospodarczą wychodzić na rynki zagraniczne. Zawarto też bariery, które w procesie internacjonalizacji występują najczęściej. Przeprowadzono badania empiryczne, na podstawie których pokazano drogi (sposoby) internacjonalizacji przedsiębiorstw polskich z sektora MSP. Odniesiono wyniki badań do polskiej specyfiki i do istniejących modeli. Artykuł napisano w oparciu o analizę literatury i badania własne.

Słowa kluczowe: internacjonalizacja, sektor MSP, umiędzynarodowienie, innowacje, przedsiębiorstwo międzynarodowe

JEL: F23 